\title{
Mima Para Tarpolarda: falsafah komunitas lokal sebagai pendampingan dan konseling kedukaan di Warjukur-Maluku
}

\author{
Helga Theressia Uspessy ${ }^{1}$, Jacob Daan Engel ${ }^{2}$ \\ ${ }^{1}$ Fakultas Teologi, Universitas Kristen Satya Wacana, Salatiga \\ 752018009@student.uksw.edu \\ ${ }^{2}$ Fakultas Teologi, Universitas Kristen Satya Wacana, Salatiga \\ jopie_engel@yahoo.com
}

\begin{abstract}
Abstrak
Pendampingan dan Konseling kedukaan berbasis budaya lokal yang disebut Mima Para Tarpolarda memberikan gambaran tentang pendampingan dan konseling yang kontekstual sesuai dengan nilainilai kearifan lokal bangsa Indonesia. Penggunaan budaya sebagai basis tindakan konseling menegaskan bahwa pendampingan dan konseling bukan hanya dilakukan oleh individu atau konselor professional yang terlatih tetapi dapat dilakukan oleh seluruh masyarakat dalam kebudayaan tertentu. Tujuan penelitian ini adalah menganalisis Mima Para Tarpolarda sebagai bentuk pendampingan dan konseling kedukaan berbasis budaya. Metode penelitian yang digunakan adalah metode penelitian kualitatif dan data yang diperoleh melalui observasi, wawancara dan study pustaka. Analisis data yang digunakan adalah analisis mengalir atau terjalin berupa pengumpulan data, pengolahan data, dan penarikan kesimpulan. Hasil yang diperoleh dari penelitian ini adalah pertama, Mima Para Tarpolarda dapat dijadikan sebagai pendampingan dan konseling kedukaan karena didalamnya terdapat nilai-nilai konseling menyangkut pemberian nasihat, bimbingan dan pertolongan oleh seluruh masyarakat kepada orang berduka. Tindakan yang dilakukan adalah bentuk reaksi kepedulian masyarakat untuk merasakan apa yang dialami oleh saudaranya akibat kematiaan anggota keluarga. Kedua, pendampingan dan konseling kedukaan yang didasarkan pada nilai kearifan lokal Mima Para Tarpolarda memberikan penyembuhan secara holistik dalam kehidupan orang berduka karena seluruh masyarakat memiliki sikap empati dan solidaritas.
\end{abstract}

Kata Kunci: Mima Para Tarpolarda, Pendampingan, Konseling Kedukaan Berbasis Budaya.

Abstract

Local culture-based grief guidance and counseling called Mima Para Tarpolarda provides an overview of contextual guidance and 
counseling in accordance with the values of Indonesian local wisdom. The use of culture as a basis for counseling actions confirms that counseling and counseling is not only done by individuals or professional counselors who are trained but can be done by all people in a particular culture. The purpose of this study is to examine Mima Para Tarpolarda as a form of cultural-based grief guidance and counseling. The research method used is qualitative research methods and data obtained through observation, interviews and literature study. Analysis of the data used is a flowing or intertwined analysis in the form of collecting data processing data, and drawing conclusions. The results obtained from this study are first, Mima Para Tarpolarda can be used as guidance and grief counseling because in it there are counseling values regarding the provision of advice, guidance and assistance by the whole community to the bereaved. The action taken is a form of public awareness reaction to feel what is experienced by his brother due to the death of family members. Second, guidance and grief counseling based on the local wisdom values of Mima Para Tarpolarda provide holistic healing in the lives of the bereaved because the whole community has an attitude of empathy and solidarity.

Keywords: Mima Para Tarpolarda, Assistance, Culture-Based Grief Counseling

\section{PENDAHULUAN}

Warjukur merupakan desa yang terletak di daerah terpencil Kabupaten Kepulauan Aru-Maluku. Dalam perkembangannya, masyarakat setempat masih menjunjung tinggi kebudayaan, nilai kekerabatan, gotong royong, kebersamaan dan kekeluargaan. Nilai-nilai diatas dihidupi melalui sebuah falsafah lokal yang disebut Mima Para Tarpolarda. Falsafah ini lahir dari budaya dan pengalaman bersama sehingga kemudian ditransmisikan dari generasi ke gerenasi dan menjadi cerminan kearifan lokal masyarakat setempat.

Dalam konteks masa kini nilai kearifan lokal ini digunakan dalam upaya pencapaian tujuan hidup dan mengatasi permasalahan sosial dalam masyarakat. Nilai ini diaplikasikan melalui acara/ritual baik yang berhubungan dengan dimensi kebahagiaan dan dukacita/masalah sosial masyarakat. Adapun acara/ritual yang berhubungan dengan dimensi kebahagiaan seperti pembuatan dan peresmian rumah baru, proses pembuatan perahu belang (perahu tradisional masyarakat Warjukur), pembersihan negeri, upacara perkawinan adat dan upacara harihari besar Gerejawi. Sedangkan acara/ritual yang berhubungan dengan dukacita/masalah sosial seperti kekerasan dalam rumah tangga, kekacauan akibat mengkonsumsi minum keras, kehilangan rumah/harta benda dan peristiwa kematian. Dalam 
hubungannya dengan dua dimensi kehidupan diatas maka nilai kearifan lokal Mima Para Tarpolarda berfungsi untuk saling membantu, memberi masukan dan memberi pendampingan bagi masyarakat. Oleh karena itu, dalam artikel penulis memfokuskan pada masalah kedukaan yang diakibatkan oleh kematian anggota keluarga.

Kematian merupakan suatu keniscayaan bagi manusia itu sendiri sehingga semua orang percaya bahwa pada suatu saat nanti mereka akan meninggal (Astuti, 2005). Fenomena ini menimbulkan kehilangan yang sangat besar bagi keluarga yang ditinggalkan karena fisik tidak lagi bersentuhan secara langsung. Hal ini merupakan pengalaman emosional yang paling menyedihkan yang dihadapi semua orang (Howarth, 2011). Sehingga apa yang dirasakan memunculkan ekspresi kesedihan dan keinginan untuk mengenang yang dikasihinya (Lensing, 2001).

Bagi (Cynthia \& Pehrsson, 2008) peristiwa ini merupakan fenomena yang universal tetapi orang meresponsnya dengan beragam. Adapun respon yang ditimbulkan dari pengalaman ini adalah trauma, respon emosional, kognitif, fisik, dan perilaku. Respons ini dapat ditemui dalam jangka waktu yang berbeda dan tidak dapat ditentukan, sehingga menimbulkan depresi hingga kemarahan oleh yang berduka. Hal ini sejalan dengan pemikiran (Wiryasaputra, 2003) yang menyebutkan bahwa kedukaan bukan hanya menyangkut proses kognitif dan emotif melainkan menyangkut seluruh aspek kehidupan manusia (fisik, mental: kognitif dan emotif, spititual dan sosial) dan biasanya kedukaan muncul ketika orang mulai menyadari adanya sesuatu yang bernilai atau dianggap hilang terjadi secara spontan atau mendadak. Dukacita yang dialami merupakan emosi yang melibatkan perasaan karena akan menutup sesorang dari pemenuhan pengharapan, mimpi, aspirasi sehingga menimbulkan frustasi yang sangat mendalam dan sukar untuk dijangkau, didefenisikan atau dijelaskan kepada siapapun. Hal ini merupakan tanggapan atas peristiwa kehilangan yang sementara dialami (Krisetya, 2015).

Kedukaan juga adalah suatu proses yang menggunakan banyak waktu dan aktivitas. Kedukaan bukanlah peristiwa yang abadi karena seiring berjalannya waktu ia akan berakhir (Abineno, 2016). Selain itu, hal ini merupakan tanggapan almiah penduka atas kehilangan sesuatu yang menjadi bagian utuh dari hidupnya yang dianggap berharga dan bernilai (Wiryasaputra, 2019). Penjelasan tentang dukacita kematian seperti yang dijelaskan diatas sejalan dengan yang dialami oleh masyarakat Warjukur. Mengingat Warjukur merupakan desa kecil yang terdiri dari $121 \mathrm{kk}$ maka bagi mereka, kematian merupakan peristiwa duka 
yang mengakibatkan kehilangan satu kekuatan dalam komunitas dan berpengaruh pada jumlah anggota masyarakat yang semakin menurun. Menarik untuk dipelajari, bahwa duka yang dirasakan bukan hanya terjadi pada keluarga berduka, tetapi juga dirasakan oleh seluruh anggota masyarakat. Bagi mereka, peristiwa ini menjadi perhatian dan tanggungan bersama untuk saling mendukung dan memberikan bantuan, melewati duka bersama dan mencari solusi atas masalah yang terjadi.

Hal ini dilakukan untuk mengantisipasi respon negatif seperti sakit, kemarahan, trauma dan depresi yang berkenjangan akibat kedukaan. Dalam hal ini, masyarakat hadir untuk memberikan dukungan baik secara moril maupun materil sebagai bentuk solidaritas dan rasa kekeluargaan bagi yang berduka. Hal ini dilatarbelakangi oleh tradisi yang berkembang melalui falsafah lokal kehidupan Mima Para Tarpolarda. Penulis melihat bahwa nilai sosial yang terkandung dalam falsafah ini seperti empati, solidaritas dan pemberian pertolongan merupakan nilai yang terkandung dalam layanan bimbingan dan konseling. Namun didalam artikel ini penulis menggunakan istilah pendampingan dan konseling kedukaan karena istilah pendampingan memiliki arti luas yang didalamnya menyangkut fungsi bimbingan yang akan dibahas dalam hasil dan pembahasan. Selain itu, istilah ini juga tidak hanya merujuk pada pemberian nasihat dan bimbingan saja tetapi merujuk pada aksi dan tindakan nyata dari komunitas lokal Warjukur.

Dengan demikian, penelitian ini bertujuan untuk menganalisis tentang falsafah Mima Para Tarpolarda, sebagai bentuk pendampingan dan konseling kedukaan berbasis budaya di Warjukur-Kabupaten Kepulauan Aru-Maluku

\section{METODE PENELITIAN}

Penelitian ini dilakukan di Desa Warjukur- Kabupaten Kepulauan Aru-Maluku karena desa ini masih menjujung tinggi nilai falsafah Mima Para Tarpolarda. Metode penelitian yang digunakan adalah kualitatif dengan pendekatan deskriptif untuk memperoleh data yang mendalam dari narasumber. Metode ini didasarkan pada deskripsi yang jelas dan detail, sehingga penyajian atas temuan akan sangat kompleks, rinci dan komprehensif sesuai dengan fenomena yang terjadi (Denzin \& Lincoln, 2011). Penelitian kualitatif sangat cocok digunakan untuk meneliti hal-hal yang berkaitan dengan interaksi sosial dan perasaan orang lain yang paling utama ialah untuk memastikan suatu kebenaran data sosial (Sugianto, 2015). Metode ini akan membahas rancangan yang akan digunakan dalam penelitian, kemudian membahas sampel penelitian dan pengumpulan data 
serta proses perekaman data secara keseluruhan.

Dalam proses pengambilan data, teknik yang digunakan berupa Pertama observasi, yakni peneliti langsung turun ke lapangan untuk mengamati perilau dan aktivitas individu-individu di lokasi penelitian. Kedua, wawancara yang mendalam. Teknik ini dilakukan dengan cara melakukan wawancara berhadap-hadapan (langsung) dengan partisipan, mewawancarai mereka dengan telepon, atau terlibat dalam wawancara dalam kelompok tertentu terkait dengan pemaknaan falsafah Mima Para Tarpolarda dalam kehidupan sosial msayarkat Warjukur (Creswell, 2010). Selain itu, kajian literatur digunakan guna memperoleh landasan teori dari buku. Subjek penelitian yang akan diwawancarai ialah para tua-tua adat yang mengetahui secara langsung asal-usul dan konsep Mima Para Tarpolarda bagi kehidupan masyarakat Aru-Maluku.

Teknik analisis data yang digunakan gunakan adalah analisis mengalir dan terjalin. Teknik analisis mengalir atau saling terjalin dilakukan dalam beberapa tahap yakni pengumpulan data, pengolahan data, dan penarikan kesimpulan. Adapun Langkahlangkah yang di lakukan dalam analisis data ini antara lain: reduksi data, penyajian data dan penarikan kesimpulan.

\section{HASIL DAN PEMBAHASAN}

\section{Hasil Penelitian}

Pelaksanaan pendampingan dan konseling kedukaan di desa Warjukur, Kabupaten Kepulauan Aru-Maluku dilakukan untuk menggali kembali nilai-nilai kerifan lokal sebagai bentuk pendampingan dan konseling kedukaan berbasis budaya. Berdasarkan metode penelitian kualitatif, penulis bermaksud untuk mendeskrisipkan proses dan bentuk layanan pendampingan dan konseling kedukaan dengan menggunakan nilai kearifaan lokal Mima Para Tarpolarda sebagai sebuah falsafah komunitas lokal untuk memberikan penyembuhan dan pertolongan secara holistic bagi kehidupan orang berduka akibat kematian berdasarkan dari hasil observasi dan wawancara dengan tua-tua adat (para tetua adat) dan masyarakat setempat. Seperti yang telah dijelaskan dalam bagian pendahuluan bahwa didalam falsafah ini terkadung nilai-nilai bimbingan dan konseling seperti empati, dan pemberian pertolongan, sehingga dapat digunakasn sebagai proses pendampingan dan konseling. Dalam pelaksanaanya terdapat dua proses yang dilakukan yaitu pendampingan dan konseling. Sebelum membahas tentang dua proses ini, penulis akan menjelaskan terlebih dahulu tentang makna dari falsafah Mima Para Tarpolarda.

Sejak dahulu falsafah komunitas lokal ini hadir dan menjadi bagian 
tak terpisahkan dari masyarakat setempat. Mereka merasa perlu untuk menciptakan falsafah ini untuk mengintegrasi masyarakat dan sebagai bentuk solidaritas dalam menata kelangsungan hidup dan menangani masalah secara bersamasama sebagai sebuah komunitas. Berdasarkan hasil wawancara yang dilakukan dengan tua adat, mereka mengatakan bahwa jauh sebelum terbentuknya desa Warjukur, falsafah ini telah ada dan berkembang, kemudian hal ini menjadi tegas dan kuat ketika adanya tiga datuk yang hadir di Warjukur sebagai awal terbentunya desa ini.

Mima Para Tarpolarda, berasal dari akar kata Poler yang berarti Persekutuan. Poler lahir dari dalam hati dan diri manusia tanpa dipaksakan untuk merasakan apa yang dialami oleh masyarakat yang membutuhkan pertolongan. Masyarakat setempat percaya bahwa jika setiap individu yang mengamalkan Poler dalam kehidupannya dengan sungguhsungguh maka ada banyak keberuntungan yang dihasilkan dalam kehidupannya dan berdampak bagi kesejahteraan hidup bersama sebagai sebuah komunitas.

Didalam Poler terdapat Lusisilapi yang artinya kasih sayang. Kata ini kemudian dibagi menjadi dua suku kata yaitu Lusi yang artinya sesuatu yang terlantar yang harus diperbaiki, diatur dan dijaga dengan kasih sayang, dan Lapi yang berhubungan dengan kecelakan. Kecelakaan yang dimaksuad adalah masalah sosial seperti kedukaan dan kematian. Dalam arti ini falsafah tersebut hadir untuk melindungi anggota masyarakatnya dari kemalangan hidup. Defenisi diatas memperlihatkan fungsi falsafah sebagai kekuatan yang mengikat dan menjadi cerminan nilai kearifan lokal dan identitas masyarakat setempat. Arti lain dari kata Poler ialah tidak mengurangi perasaan orang lain terkhusunya dalam lingkungan keluarga. Artinya, setiap anggota keluarga harus mampu menjaga perasaan anggota keluarga lainnya dan tidak melukai sebagai wujud dari keluarga sejati yang berakar falsafah Mima Para Tarpolarda.

Berdasarkan pemaknaan dari falsafah Mima Para Tarpolarda maka masyarakat setempat menggunakannya sebagai upaya penyembuhan dan pertolongan kepada seluruh masyarakat yang mengalami kesulitan hidup khusunya masalah kedukaan. Berikut deskripsi tentang proses pendampingan dan konseling berbasis budaya bagi keluarga berduka melalui falsafah Mima Para Tarpolarda dalam kaitannya kematian anggota keluarga.

\section{Proses pendampingan}

Adapun bentuk Pendampingan yang dilakukan oleh masyarakat Warjukur, pertama-tama dengan pemanggilan seluruh anggota 
keluarga dari rumah ke rumah oleh pemerintah adat yang diwakili oleh tua adat/orang yang dituakan. Dalam proses ini, tua adat memanggil dengan menggunakan kalimat MimaMima Para Tarpolarda, MimaMima Samasikoalisan. Artinya: Mari-Mari basudara semua kita menolong saudara kita yang sementara mengalami kesusahan. Jika keluarga yang mendengar kalimat ini maka secara langsung menuju ke rumah/keluarga yang sedang berduka. Berdasarkan hasil wawancara dikatakan bahwa kalimat ini mengandung nilai kekerabatan, kerukunan dan solidaritas yang sangat kuat karena bukti menyatakan bahwa jika ada keluarga yang sedang mengalami konflik dengan keluarga yang berduka ketika mendengar kalimat ini maka keluarga yang bersangkutan secara langsung mengesampingkan masalah/konflik yang sedang dialami dengan keluarga yang berduka.

Dikatakan dalam istilah sederhana bahwa: selanjutnya masyarakat menuju dapur dari keluarga berduka dan membuka tutup saji (penutup makanan) yang berada diatas meja makan. Ini merupakan istilah yang digunakan untuk mempersiapkan proses pemakaman tanpa campur tangan keluarga berduka. Dimulai dari pembuatan tenda duka, penggalian kubur, pembuatan peti dan pembersihan jenazah dilakukan oleh anggota masyarakat. Setelah persiapan pemakaman telah dilaksanakan oleh pemerintah adat dan masyarakat maka diserahkan bagi gereja (pendeta dan majelis jemaat) untuk memberikan pelayanan dalam ibadah pemakaman sampai proses penguburan. Setelah ibadah penguburan, maka dilakukan penghiburan bagi keluarga berduka yang di sebut dengan 3 malam. Hal ini bertujuan untuk melakukan proses pendampingan bagi keluarga. Artinya bahwa dari setiap proses yang dilakukan merupakan upaya masyarakat dalam menunjukan kepedulian bagi keluarga berduka melalui falsafah Mima Para Tarpolarda.

\section{Proses konseling}

Dalam proses ini konseling yang dilakukan dalam komunitas Warjukur berupa pemberian nasehat oleh orang yang dituakan dalam komunitas dan juga penguatan dari pelayan gereja. Dalam konteks Warjukur, nasihat atau petuah yang disampaikan oleh orang tatua (orang yang dituakan) sangat berpengaruh bagi individu. Nasihat yang disampaikan merupakan simbol kekuatan bagi individu yang mengalami kedukaan.

Selain itu, fungsi pelayan gereja diharapkan memberikan dukungan rohani bagi keluarga berduka melalui refleksi teologis bahkan doa yang disampaikan. Mengingat Warjukur merupakan sebuah desa kecil yang terletak di pedalaman-Aru-Maluku maka akses kesehatan dan perawatan psikologi seringkali tidak dapat 
dinikmati dengan baik. Sehingga jika terjadi gangguan fisik masyarakat seringkali menggunakan obat-obatan tradisional yang diambil dari alam dan gangguan seperti depresi dan menutup diri dari lingkungan biasanya meminta bantuan dan nasihat dan perawatan dari orang tatua/orang yang dituakan atau tuatua adat.

\section{Pembahasan}

Penulis melihat bahwa dalam falsafah masyarakat Warjukur memiliki nilai yang sama dalam ilmu bimbingan dan konseling. Secara defenisi menurut (Sulistiyarin, 2014) pendampingan dan konseling adalah layanan/bantuan yang diberikan kepada konseli baik perorangan atau kelompok agar mampu mandiri berkembang secara optimal dalam bidang pribadi, sosial, belajar, karier, keluarga dan keagamaan melalui berbagai jenis layanan dan kegiatan pendukung berdasarkan normanorma yang berlaku. Atau bimbingan konseling juga dapat diartikan proses pemberian bantuan yang dilakukan melalui konseling yang dilakukan seorang ahli (konselor) kepada konseli (individu), sehingga individu atau kelompok individu itu dapat memahami diri sendiri untuk mencapai perkembangan yang optimal, untuk mewujudkan dan merencanakan masa depan yang lebih baik untuk mencapai kesejahteraan hidup.
Proses penyelesaian masalah yang dialami individu atau kelompok dalam konteks kedukaan merupakan sebuah tindakan kolektif yang diterapkan dalam masyarakat homogen di desa Warjukur. Mima Para Tarpolarda merupakan sebuah budaya yang mengandung nilai dan pesan sosial dalam menjaga keseimbangan hidup bersama, menolong, mendampingi dan mengatasi masalah masyarakat khususnya kedukaan akibat kematian anggota keluarga.

Dalam peristiwa ini kedukaan menjadi masalah penting untuk dapat diselesaikan bersama dalam sebuah komunitas lokal. Salah satu bentuk upaya yang dilakukan untuk memberikan penyembuhan dan pertolongan secara holistic adalah dengan pendekatan kebudayaan karena sesungguhnya setiap masyarakat yang mengalami kedukaan tidak dapat dipisahkan dari tempat atau budaya dimana dia berasal. Wiryasaputra menegaskan tentang pentingnya budaya dalam membantu individu melewati masa dukanya. Menurutnya setiap kebudayaan pasti memiliki seperangkat dan kebijaksanaan dalam membantu warganya melewati kematian dan kedukaan. Artinya, setiap kali masyarakat berkumpul untuk melakukan upacara maka pada saat itu mereka sering kali mereka mewujudkan diri sebagai apa yang disebutnya sebagai caring community bagi keluarga yang ditinggalkan. 
Dengan adanya hal itu maka setiap masyarakat tertentu dapat melintasi masa-masa sulit yang sementara dialaminya (Wiryasaputra, 2003). Artikel ini menyajikan sebuah konsep layanan pendampingan dan konseling kedukaan yang berbeda dengan konseling kedukaan pada umumnya.

Berikut beberapa hasil penelitian terdahulu terkait dengan layanan pendampingan dan konseling kedukaan yang peneliti temui dalam kajian literatur adalah sebagai berikut (Cynthia \& Pehrsson, 2008) dalam tulisannya menyajikan sebuah konseling kedukaan melalui biblioteraphy. Terapi ini berfokus pada penggunaan sastra melalui buku atau literatur yang digunakan bagi klien untuk mengekslorasi kekuatan diri sendiri melalui cerita yang disajikan. (Huges, 1988) dalam tulisannya, mencoba memfasilitasi proses penyebuhan dengan cara mencatat daftar kebencian yang bertujuan untuk menyembuhkan luka dan bukan untuk menyalahnkan/ menghukum siapapun. Sedangkan (Riordan \& Allen, 1989) memberikan sebuah konsep baru tentang rumah duka sebagai model konseling kedukaan. Hal ini dilakukan sebagai sarana, layanan dan fasilitas pemakaman. Sedikit berbeda dengan penulis global dalam konteks Indonesia, penelitian tentang pendampingan dan konseling begitu menarik karena para penulis melihat bahwa budaya (falsafah lokal) dapat digunakan sebagai bentuk konseling anatara lain (Sukamto, 2017) dalam tulisannya ia menawarkan bentuk pendampingan dan koseling budaya yang dilakukan dengan cara duduk/berkumpul bersama sembari berbincang-bincang menggunakan bahasa Jawa sebagai pengantar yang disebut Jagongan.

Di Maluku sendiri pendampingan dan konseling kedukaan telah diteliti oleh (Latuny, 2017) dalam tulisannya, membahas tentang konsep pendampingan dan konseling kedukaan yang dilakukan melalui pengucapan syukur atau kumpul keluarga bersama jemaat atas peristiwa kematian yang dikenal dengan Tunjuitam.

Berbeda dengan penelitian sebelumnya, penelitian ini akan menyoroti tentang peran nilai budaya dari falsafah yang menjadi dasar agar setiap masyarakat mampu saling mengasihi satu dengan yang lain melalui Mima Para Tarpolarda yang memiliki nilai-nilai dalam konsep pendampingan dan konseling kedukaan. Selain itu juga, penelitian ini memperlihatkan bahwa pendampingan dan konseling kedukaan tidak hanya dilakukan oleh individu atau dan konselor professional tetapi melibatkan peran aktif seluruh anggota masyarakat, pemerintah adat dan Gereja dalam menangani peristiwa kematian sebagai upaya kepedulian sosial. Selain itu, pendampingan dan 
konseling bagi keluarga berduka dilakukan secara bertahap dari adanya kabar tentang kematian sampai pada ucapan syukur dan penghiburan yang dikenal dengan 3 malam.

Hasil penelitian dan kajian penelitian sejenis mendorong peneliti untuk mengembangkan sebuah teknik pendampingan dan konseling kedukaan berdasarkan nilai-nilai tradisi dan kearifan lokal masyarakat di desa Warjukur melalui Mima Para Tarpolarda. Berdasarkan pengetahuan masyarakat di Warjukur falsafah Mima Para Tarpolarda merupakan sebuah tradisi dan budaya yang telah menjadi identitas bersama dalam hidup saling berdampingan. Hal ini merupakan sebuah pengetahuan dan kebiasaan yang sejak dahulu telah menjadi dasar agar masyarakat Warjukur yang terus bergenerasi dapat hidup berdampingan dan harmonis dan falsafah ini dipelajari dari zaman dahulu melalui para leluhur (orang yang lebih tua) dan pengetahuan ini terus ditransmisikan hingga masa kini terhadap generasi muda. Hal ini sejalan dengan penegasan dari (Hasan, 2011) bahwa budaya merupakan pola pengetahuan manusia, kepercayaan dan kebiasaan yang terintegrasi dan tergantung pada kapasitas pemikiran simbolis dan pembelajaran sosial. Dalam ulasannya (SJ, 1989) menekankan tentang aspek formal dari kebudayaan terletak pada karya budi yang mentransformasikan data, fakta, situasi, kejadian alam yang dihadapinya menjadi nilai bagi manusia. Mima Para Tarpolarda merupakan karya dari pikiran para leluhur untuk menciptakan rasa solidaritas, kepedulian dan empati dalam kehidupan komunitas lokal sehingga hal ini terus berlanjut dan mecerminkan kondisi dan fakta sosial yang terjadi untuk saling berdampingan satu dengan yang lain. Kekuatan yang meningat mampu mendorong seluruh masyarakat untuk aktif memberikan pertolongan bagi saudara mereka yang mengalami kedukaan. Dalam falsafah Mima Para Tarpolarda nilai-nilai kehidupan dapat dijadikan sebagai pedoman dan tata cara bersosial.

Berdasarkan hasil wawancara dan observasi terdapat beberapa nilai-nilai sosial yang terkandung dalam falsafah ini sebagai berikut kemanusiaan, kebersamaan, solidaritas, persahabatan, persekutuan, kerukunan, kekeluargaan dan kasih sayang. Nilai-nilai tersebut sejalan dengan yang disampaikan oleh (Uhi, 2016) tentang 5 nilai budaya yang yaitu: Nilai Ketuhanan, Nilai Kemanusiaan, Nilai Solidaritas masyarakat, Nilai Persaudaraan dan Nilai Kerukunan. Nilai ini tidak hanya lahir dan berkembang dari tradisi-tradisi adat dan budya tetapi lahir dan terbentuk dalam proses bertumbuh dan berkembangnya masyarakat. Kelima nilai budaya diatas lahir sebagai 
bentuk rasa kepedulian dan empati bagi masyarakat yang berada dalam kesulitah hidup. Beberapa nilai yang telah disampaikan menjadi sebuah basis tindakan pendampingan dan konseling bagi orang berduka. Sehingga dapat dijadikan sebagai sebuah pendekatan pendampingan dan konseling. Berikut adalah pembahasan terkait bagaimana falsafah komunitas lokal yang disebut Mima Para Tarpolarda dapat dijadikan sebagai pendekatan pendampingan dan konseling berdasarkan hasil temuan lapangan dan kajian teori.

\section{Pendampingan}

Van Beek mengemukakan bahwa, istilah pendampingan berasal dari kata "mendampingi" yang merupakan suatu kegiatan menolong orang lain karena suatu sebab untuk didampingi. Dalam proses pendampingan posisi pendamping dan yang didampingi berada dalam kesetaraan dan memiliki kedudukan yang seimbang dalam hubungan timbal balik yang serasi. Hubungan yang dibagun dalam proses pendampingan membuat pendampingan memiliki arti sebagai kegiatan kemitraan, bahu-membahu, menemani, berbagi untuk saling menumbuhkan dan melengkapi. Pendampingan memiliki aspek yang lebih luas, yang mencakup pemberian nasihat dan bimbingan (Beek, 2017).

Pendampingan seperti yang dijelaskan oleh Van Beek semakin mempertegas proses layanan pendampingan kedukaan yang dilakukan dalam Komunitas Warjukur bahwa peran aktif dari seluruh masyarakat merupakan usaha bahu-membahu, kemitraan, saling menumbuhkan dan melengkapi. Dapat dilihat bersama bahwa ketika salah satu anggota masyarakat atau keluarga yang meninggal dunia maka seluruh masyarakat secara kolektif merasakan apa yang dirasakan atas keluarga yang sedang berduka. Sehingga mereka saling memberikan bantuan dan menyelesaikan persoalan kehidupan secara bersama-sama. Setiap masyarakat dipimpin oleh para tua adat (sebutan orang yang di homati) datang untuk mendampingi keluarga yang sedang beduka. Dapat dipahami bahwa bagi komunitas Warjukur Pendampingan merupakan aspek yang diutamakan sebelum proses konseling dilakukan.

Pendampingan merupakan hal mendasar untuk membantu orang berduka sejak pertama kali mendengar, merasakan dan mengalami peristiwa kedukaan tersebut. Pendampingan merupakan pertolongan awal yang dapat dilakukan masyarakat kepada orang berduka dan hal ini juga akan menentukan keadaan jiwa dan fisik seseorang setelah mengalami kedukaan, artinya jika pertolangan awal telah berhasil dilakukan maka pada tahap-tahap selanjutnya hal-hal negatif seperti depresi, merasa ada yang hilang dan gangguan fisik 
lainnya dapat terhindari karena melalui falsafah ini mereka saling memiliki antara satu dengan yang lain sehingga tidak ada yang merasa kehilangan meskipun ada tetapi tidak akan berlangsung dalam jangka waktu yang lama. Hal yang sama juga dijelaskan oleh (Engel, 2016) bahwa pendampingan merupakan sebuah usaha untuk membantu individu dalam mengembangkan kemampuan berdasarkan potensi dan nilai yang dianut.

Pendampingan tidak hanya meringankan beban penderitaan tetapi juga menumbuhkan, dan menumbuhkan orang dalam kehidupan spiritualnya untuk membina hubungan dengan sesama. Berdasarkan pengertian diatas maka Engel menguaraikan tentang 5 fungsi pendampingan yaitu:

\section{Fungsi Bimbingan (Guiding)}

Fungsi bimbingan dapat membantu individu yang berada dalam kebingungan untuk menentukan pilihan dan keputusan yang pasti. Fungsi ini dibutuhkan untuk individu dalam menghadapi perubahan yang terjadi dalam hidupnya. Bimbingan yang dilakukan bertujuan agar setiap individu mampu menunjukan sikap positf dan respek terhadap diri sendiri dan orang lain, memiliki kemampuan dalam menyelesaikan konflik baik yang bersifat internal maupun dengan orang lain, mudah mengambil keputusan dan yang paling penting adalah memiliki sikap toleransi terhadap umat beragama untuk saling memelihara hak dan kewajiban masing-masing (Yusuf \& Nurihsan, 2012).

\section{Fungsi Penopangan \\ (Sustaining)}

Fungsi menopang membantu konseli yang mengalami luka dan sakit untuk bertahan menghadapi dan melewati masa-masa sulit yang dialami. Fungsi ini membantu individu untuk menerima kenyataan, mandiri dalam keadaan yang baru serta bertumbuh secara penuh dan utuh.

\section{Fungsi Penyembuhan (Healing)}

Fungsi ini dapat membantu individu untuk mengungkapkan perasaan hatinya yang terdalam. Fungsi penyembuhan mengatasi kerusakan dilakukan dengan mengembalikan individu pada suatu keutuhan dan menuntunya kea rah yang lebih baik dari sebelumnya.

\section{Fungsi memulihkan atau memperbaiki hubungan (Reconciling)}

Fungsi ini membantu konseli memperbaiki kembali hubungan yang rusak antara dirinya dan orang lain. Menolong Konseli memanfaatkan kesalahan yang telah dilakukan orang lain dan memberi mereka pengampuanan. Dengan demikian fungsi ini mampu memulihkan kembali adanya keretakan dalam hubungan antara konseli dengan orang lain. 


\section{Fungsi memelihara atau mengasuh (Nurturing)}

Dengan menggunakan pemikiran dari Cinibel, Engel menjelaskan bahwa fungsi ini memampukan konseli untuk mengembangkan potensi-potensi yang diberikan Allah kepada dirinya. Dengan demikian, pendampingan dan konseling melaksanakan fungsi penggembalaan dengan tujuan utama mengutuhkan kehidupan manusia dalam segala aspek kehidupannya yakni fisik, sosial, mental, spiritualnya. Sehingga fungsi ini menjadi fungsi yang terkahir dari pendampingan dan konseling dalam masyarakat.

Kelima fungsi pendampingan yang telah dijelaskan, menyetuh aspek kehidupan komunitas Lokal Warjukur dalam upaya pengembangan layanan pendampingan bagi orang berduka. Dalam konteks masyarakat Indonesia setiap manusia memiliki pengalaman yang beragam sehingga tidak mungkin hanya dilakukan oleh satu profesi atau satu orang saja. Hal ini sejalan dengan pemikiran (Engel, 2016) yang menyebutkan bahwa pendampingan dilakukan tidak hanya menjadi tanggungjawab konselor, pendeta, pastor atau rohaniawan tetapi semua orang percaya yang terpanggil untuk melaksanakan tugas itu untuk mewujudkan kasih, perhatian dan kepedulian terhadap sesama.

$\begin{array}{crr}\begin{array}{c}\text { Terdapat } \\ \text { pendampingan }\end{array} & \text { tiga } & \text { jenis } \\ \text { menurut }\end{array}$
(Wiryasaputra, 2019) yaitu: Pertama, pendampingan eksistensial. Pendampingan ini dilakukan oleh semua anggota keluarga manusia secara universal, dimanapun mereka tinggal. Kedua, pendampingan fungsional. Pendampingan ini dilakukan oleh para pengemban profesi selain konslelor yang ingin memaknai sikap dan ketrampilan konseling untu member nilai tambah bagi layanan profesinya seperti dokter, perawat, pekerja sosial atau petugas gerejawi. Ketiga, pendampingan profesional. Bantuan ini dilakukan oleh kaum professional yang telah dididik dan dilatih untuk melakukan konseling profesional. Pendampingan orang berduka yang diberikan melalui falsafah Mima Para Tarpolarda menegaskan tentang dua jenis pendampingan yaitu pendampingan eksistensial dan pendampingan fungsional. Kedua jenis pendampingan berdasarkan falsafah ini memperlihatkan bahwa pertolongan yang diberikan kepada berduka tidak harus dilakukan oleh konselor professional yang terlatih tetapi dapat dilakukan oleh masyarakat secara kolektif.

\section{Konseling}

(Worden, 2009) dalam bukunya Grief Counseling and Grief Therapy menyatakan tujuan keseluruhan dari konseling kedukaan adalah untuk membantu individu beradaptasi dengan kehilangan orang yang 
dicintai dan dapat menyesuaikan diri dengan kenyataan baru. Selain itu, ada 4 tujuan spesifik yang berhubungan dengan kedukaan yaitu: (1) meningkatkan realitas kehilangan, (2) membantu konseli mengatasi rasa sakit emosional dan perilaku, (3) membantu konseli mengatasi berbagai hambatan untuk penyesuaian kembali setelah kehilangan, dan (4) membantu konseli menemukan cara untuk mempertahankan ikatan dengan almarhum sambil merasa nyaman berinvestasi kembali dalam kehidupan.

Dalam komunitas lokal di Warjukur konseling adalah upaya yang dilakukan apabila masalah kedukaan berlarut-larut dalam jangka waktu yang tidak dapat ditentukan hingga menimbulkan penyakit dan perubahan dalam hubungan sosial maka tidak cukup hanya dengan pendampingan tetapi juga konseling. Akan tetapi konseling yang dilakukan bukan dari konselor professional tetapi dari para tua-tua adat (orang yang dituakan) dalam komunitas adat. Kekuatan budaya yang mengikat mempu membuat orang berduka mendapatkan proses penyembuhan holistic dari pemberian nasihat tetapi juga tindakan menemukan solusi seperti mencari obat-obatan alam sebagai sarana penyembuh khususnya bagi orang-orang yang mengalami gangguan fisik seperti sakit yang berkepanjangan.
Konseling berperan dalam suatu krisis kemalangan hidup baik itu individu maupun keluarga, bahkan krisis perubahan sosial dalam masyarakat. Konseling menjadi sarana penyembuh untuk membantu memperbaiki yang paling sulit, yang sementara dialami oleh individu (Engel, 2016). Selain itu juga konseling merupakan suatu upaya untuk memanusiakan sesama manusia. Dalam upaya memanusiakan itulah terkandung makna pemberdayaan (Engel, 2018). Sehingga seseorang dapat menemukan makna hidup (meaning of life) karena makna hidup sangat penting dan berharga serta memberikan nilai khusus bagi sesorang dan layak dijadikan tujuan dalam kehidupannya (Engel, 2014).

Adapun tujuan konseling adalah untuk membantu klien menyelesaikan problem yang mengganggu mereka. Konseling juga dimaksudkan untuk membantu klien mengembangkan beragam cara yang lebih positif untuk menyikapi hidup. Setiap individu yang meminta bantuan konseling dengan bermacam-macam sebab dan untuk berbagai tujuan. Mereka meminta bantuan untuk mengatasi kesedihannya. Selain itu konseling membantu menumbuhkan dan mengembangkan ketrampilan pribadi. Konseling dapat dilakukan oleh konselor tetapi juga yang bukan konselor karena ketrampilan konseling ketrampilan yang paling 
penting adalah berkomunikasi sehingga dapat membantu orang lain. Terutama bagi mereka yang bukan konselor dapat digunakan dalam pergaulan sehari-hari (Musnamar, 2004). Konseling juga bertujuan untuk membantu konseli menemukan konsep dirinya yang lebih positif lewat komunikasi yang menempatkan konseli sebagai orang yang palsing berharga, yang penting dan orang yang memiliki petensi positif dengan penerimaan tanpa syarat (unconditional positive regard) yaitu menerima konseli apa adanya (Komalasari, Wahyuni, \& Karsih, 2011). Dengan demikian, tujuan utama dari layanan konseling adalah menolong konsli agar mampu memngalami pengalamannya dan menerima apa yang terjadi atas dirinya secara penuh dan utuh.

\section{SIMPULAN}

Berdasarkan hasil penelitian dan pembahasan dapat ditarik kesimpulan bahwa pendekatan pendampingan dan konseling kedukaan berbasis budaya yang dilakukan oleh masyarakat lokal di Warjukur merupakan upaya mengkontekstualisasikan sebuah tindakan konseling yang sesuai dengan jati diri dan identitas bangsa Indonesia sebagai bangsa yang memiliki keanekaragamaan budaya yang dapat digunakan untuk membantu dan menolong orang lain. Artinya, artikel ini hendak menegaskan bahwa pendampingan dan konseling bukan hanya dilakukan oleh individu atau konselor terlatih tetapi juga seluruh masyarakat yang mempunyai pengalaman bersama melalui kebudayaan tertentu.

Praktek hidup masyarakat Warjukur melalui falsafah lokal yang disebut Mima Para Tarpolarda dapat dijadikan sebagai bentuk pendampingan dan konseling kedukaan bagi komunitas lokal. Selain itu juga hal ini dapat memberikan gambaran bagi masyarakat berbudaya di Indonesia secara menyeluruh untuk menggunakan nilai-nilai kearifan lokal sebagai upaya pendampingan dan konseling, khususnya bagi masyarakat pedesaan yang jauh dari akses kesehatan dan para konselor professional yang terlatih karena pada dasarnya kedua hal ini hanya dijumpai didalam masyarakat perkotaan.

\section{DAFTAR PUSTAKA}

Abineno, J. L. (2016). Pelayanan Pastoral Kepada Orang Berduka. Jakarta: BPK Gunung Mulia.

Astuti, Y. D. (2005). Kematian Akibat Bencana dan Pengaruhnya Pada Kondisi Psikologis Survivor: Tinjauan Tantag Arti Penting Death Education. Humanitas: Indonesian Psychological Journal, 2(1), 41-53.

Beek, A. V. (2017). Pendampingan Pastoral. Jakarta: BPK Gunung Mulia. 
Creswell, J. W. (2010). Research Design: $\quad$ Pendekatan Kualitatif, Kuantitatif dan Campuran . Yogyakarta: Pustaka Pelajar.

Cynthia, B. A., \& Pehrsson, D. E. (2008). Use Bibliotherapy in the Treatment of Grief and Loss: A Guide to Current Counseling Practices. Adultspan: Journal Spring, 7(1), 32-42.

Denzin, N. K., \& Lincoln, Y. S. (2011). The Sage Handbook of Qualitative Research I. Yogyakarta: Pustaka Pelajar.

Engel, J. D. (2014). Nilai-Nilai Dasar Konseling. Yogyakarta: Kanisius.

Engel, J. D. (2016). Konseling Pastoral dan Isu-Isu Kontemporer. Yogyakarta: Kanisius.

Engel, J. D. (2016). Pastoral dan Kebutuhan Dasar Konseling. Jakarta: BPK Gunung Mulia.

Engel, J. D. (2018). Konseling Masalah Masyarakat. Yogyakarta: Kanisius.

Hasan, S. S. (2011). Pengantar Cultural Studies. Yogyakarta: Ar-Ruzz Media.

Howarth, R. A. (2011). Concepts and Controversies in Grief and Loss. Journal of Mental Health Counseling, 33(1), 410.

Huges, R. B. (1988). Grief Counseling: Facilitating the Healing Process. Journal of Counseling and Development, 67, 77-78.

Komalasari, G., Wahyuni, E., \& Karsih. (2011). Teori dan Teknik Konseling . Jakarta: PT Indeks.
Krisetya, M. (2015). Bela Rasa yang Dibagirasakan. Jakarta: Duta Ministri.

Latuny, N. C. (2017). Tunjuitam: Kumpul Keluarga sebagai Pendampingan dan konseling Kedukaan. (Tesis: Universitas Kristen Satya Wacana).

Lensing, V. (2001). Grief Support: The Role Of Funeral Service. Journal of Loss \& Trauma, 6, 45-63.

Musnamar, H. T. (2004). Membantu Memecahkan Masalah Orang Lain dengan Teknik Konseling. $\quad$ Yogyakarta: Pustaka Pelajar.

Riordan, R. J., \& Allen, L. (1989). Grief Counselin: A Funeral Home-Based Model. Journal of Couseling and Development, 67, 424-425.

SJ, J. B. (1989). Filsafat Kebudayaan: Sebuah Pengantar. Yogyakarta: Kanisius.

Sugianto, E. (2015). Menyusun Proposal Penelitian Kualitatif Skripsi dan Tesis. Yogyakarta: Suaka Medika.

Sukamto, N. (2017). Jagongan sebagai Pendampingan Pastoral Budaya (Kajian Pastoral Budaya kepada Warga Jemaat GITJ Sembaturagung-Pati yang Mengalami Kedukaan. (Tesis, Universitas Satya Wacana).

Sulistiyarin. (2014). Dasar-Dasar Konseling. Jakarta: Prestasi Pusta.

Uhi, J. A. (2016). Filsafat Kebudayan. Yogyakarta: Pustaka Pelajar.

Wiryasaputra, T. S. (2003). Mengapa Berduka: Kreatif Mengelolah 
Perasaan Duka. Yogyakarta:

Kanisius.

Wiryasaputra, T. S. (2019). Grief Psychotherapy: Psikoterapi

Kedukaan. Yogyakarta:

Kanisius.

Wiryasaputra, T. S. (2019). Konseling Pastoral: Konsep dan Penerapannya di Era Milenial. Yogyakarta: Kanisius.

Worden, W. J. (2009). Grief Counseling and Grief Therapy. New York: Springer Publishing Company.

Yusuf, S., \& Nurihsan, J. A. (2012). Landasan Bimbingan \& Konseling. Bandung: PT Remaja Rosdakarya. 